\title{
An Insula-Central Amygdala Circuit for Guiding Tastant-Reinforced Choice Behavior
}

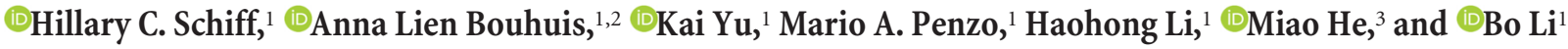 \\ ${ }^{1}$ Cold Spring Harbor Laboratory, Cold Spring Harbor, New York 11724, ${ }^{2}$ Swammerdam Institute for Life Sciences, Center for Neuroscience, University of \\ Amsterdam, 1098 XH Amsterdam, the Netherlands, and ${ }^{3}$ Institutes of Brain Science, State Key Laboratory of Medical Neurobiology, Collaborative \\ Innovation Center for Brain Science, Fudan University, Shanghai 200032, China
}

For animals to survive, they must reliably predict during foraging which substances are suitable for consumption. Despite extensive study, the neural circuit mechanisms underlying such adaptive behavior remain poorly understood. Here, using a tastant (sucrose/ quinine)-reinforced "go/no-go" task in male and female mice, we examined the anatomical and functional connectivity of the circuit linking the insular cortex (IC) to the central amygdala (CeA) and the role of this circuit in the establishment of appropriate behavioral responses. Using anatomic tracing approaches combined with optogenetics-assisted circuit mapping, we found that the gustatory region of the IC sends direct excitatory projections to the lateral division of the $\mathrm{CeA}(\mathrm{CeL})$, making monosynaptic excitatory connections with distinct populations of CeL neurons. Specific inhibition of neurotransmitter release from the CeL-projecting IC neurons prevented mice from acquiring the "no-go" response, and impaired the "go" responses in the go/no-go task. Furthermore, selective activation of the IC-CeL pathway with optogenetics drove unconditioned lick suppression in thirsty animals, induced aversive responses, and was sufficient to instruct conditioned action suppression in response to a cue predicting the optogenetic activation. These results indicate that activities in the IC-CeL circuit are critical for establishing taste-reinforced behavioral responses, including avoidance responses to an aversive tastant, and are sufficient to drive learning of anticipatory avoidance. Our findings suggest that the IC-CeL circuit plays an important role in guiding appropriate choices during foraging.

Key words: behavioral inhibition; central amygdala; go/no-go; insular cortex; optogenetics; taste

\section{Significance Statement}

An animal's ability to predict which substances are suitable for consumption and then produce an appropriate action to those substances is critical for survival. Here we found that activity in the circuit that links the insular cortex (IC) to the central amygdala (CeA) is necessary for establishing appropriate behavioral responses to taste-predicting cues. This neural circuit seems to be particularly tuned to avoid an unpleasant tastant, and is also sufficient to drive learning of such avoidance responses. These results suggest that the IC-CeA circuit is critical for generating appropriate behavioral responses during foraging when facing different choices.

\section{Introduction}

The insular cortex (IC), including the gustatory cortex (GC), plays an important role in processing taste and visceral informa-

\footnotetext{
Received June 25, 2017; revised Dec. 25, 2017; accepted Dec. 27, 2017.

Author contributions: B.L., H.S., and M.H. designed research; H.S., A.L.B., M.A.P., and H.L. performed research; K.Y. and M.H. contributed unpublished reagents/analytic tools; H.S. analyzed data; B.L. and H.S. wrote the paper. We thank A. Fontanini (Stony Brook University, New York) for critical reading of an early version of the manuscript, J. Johansen (RIKEN Brain Science Institute, Japan) for helpful discussions, P. Wulff (University of Kiel, Germany) for kindly providing the AAV.CAG.Flex.TeLC-eGFP plasmid, and members of the Li laboratory for discussions. This work was supported by grants from the National Alliance for Research on Schizophrenia and Depression (23169, B.L.), the National Natural Science Foundation of China (81428010, B.L. and 31771196, M.H.), the National Institutes of Mental Health (R01MH101214, B.L.), the Wodecroft Foundation (B.L.), the Stanley Family Foundation (B.L.), the Simons Foundation Autism Research Initiative (344904, B.L.), and the Human Frontier Science Program (RGP0015, B.L.).

The authors declare no competing financial interests.
}

tion (Yamamoto et al., 1985; Katz et al., 2001; Accolla and Carleton, 2008; Samuelsen and Fontanini, 2017). The IC is also engaged in various learning tasks, such as learning to associate a neutral tastant [also known as a conditioned stimulus (CS)] with an intrinsically aversive stimulus [also known as an unconditioned stimulus (US)], or to associate a nongustatory CS with an appetitive or aversive tastant US (Yasoshima and Yamamoto,

Correspondence should be addressed to Dr. Bo Li, 1 Bungtown Road, Cold Spring Harbor, NY 11724. E-mail: bli@cshl.edu.

H. Schiff's present address: Stony Brook University, Stony Brook, NY 11794

M.A. Penzo's present address: Unit on the Neurobiology of Affective Memory, National Institute of Mental Health

Bethesda, MD 20892.

H. Li's present address: Huazhong University of Science and Technology, Wuhan 430074, China

D0I:10.1523/JNEUROSCI.1773-17.2017

Copyright $\odot 2018$ the authors $\quad 0270-6474 / 18 / 381418-12 \$ 15.00 / 0$ 
1998; Bermúdez-Rattoni, 2004; Kusumoto-Yoshida et al., 2015; Vincis and Fontanini, 2016). In one such task, the conditioned taste aversion (CTA) task, a tastant is followed by gastric malaise and thus serves as a CS predicting an aversive consequence. Studies using this task have revealed a crucial role for the IC, as well as for inputs to the IC from the basolateral amygdala (BLA), in the acquisition and expression of CTA, indicating a requirement for plasticity in the IC in this form of Pavlovian learning (GuzmanRamos and Bermúdez-Rattoni, 2012; Maffei et al., 2012).

In another task, the "go/no-go" task in which "go" and "nogo" CSs predict the delivery of appetitive and aversive tastants, respectively, specific CS-evoked responses develop in the IC as rats or mice learn the predictive value of each CS (Gardner and Fontanini, 2014; Livneh et al., 2017). IC neurons also show CSevoked responses in a conditioned food-approaching task (Kusumoto-Yoshida et al., 2015). These findings indicate that associative learning driven by gustatory reinforcement induces plastic changes in the IC, and suggest that the IC may participate in guiding approach or avoidance responses during feeding or foraging behaviors. Consistently, pharmacological and optogenetic inhibition of the IC impairs conditioned food-approaching behavior (Kusumoto-Yoshida et al., 2015; Livneh et al., 2017). Nevertheless, how the IC participates in the generation of these behavioral responses remains unclear.

The central nucleus of the amygdala $(\mathrm{CeA})$ is a prominent downstream structure of the IC. As it is also a direct recipient of taste information from the brainstem (Carter et al., 2013), the $\mathrm{CeA}$ is anatomically positioned to process convergent taste information. Indeed, the CeA encodes taste identification and palatability, responses that follow those in the IC (Sadacca et al., 2012). The CeA also plays an important role in positively or negatively regulating reward-related behaviors and feeding (Gallagher et al., 1990; Kentridge et al., 1991; Petrovich et al., 2009; Cai et al., 2014; Robinson et al., 2014; Seo et al., 2016; Douglass et al., 2017; Kim et al., 2017). Therefore, in addition to its well known role in the learning and expression of defensive behaviors (Goosens and Maren, 2003; Wilensky et al., 2006; Ciocchi et al., 2010; Li et al., 2013), the CeA may process and use the information originating from the IC to influence taste-motivated behaviors.

To test this hypothesis, we used anatomical, electrophysiological, and circuit-based manipulation approaches. We found that an excitatory monosynaptic connection exists between the posterior division of the IC and the lateral division of the CeA $(\mathrm{CeL})$ in mice, and that activation of the IC-CeL pathway excites specific subtypes of neurons within the CeL. Selective inhibition of CeL-projecting IC neurons prevented the acquisition and expression of conditioned inhibitory response to a cue predicting an aversive tastant, and impaired the production of a conditioned response to a cue predicting a rewarding appetitive tastant in a taste-motivated go/no-go task. Furthermore, activation of the IC-CeL circuit with optogenetics produces a powerful suppression of ongoing licking behavior in thirsty mice, induces avoidance behavior, and is sufficient to instruct conditioned lick suppression. These results reveal an important role of the IC-CeL circuit in the learning and expression of flexible anticipatory behaviors in response to cues predicting an unpleasant or palatable taste.

\section{Materials and Methods}

\section{Animals}

Before surgery, mice were group-housed under a $12 \mathrm{~h}$ light-dark cycle (7:00 A.M. to 7:00 P.M. light) with food and water available ad libitum. The Som-cre (Taniguchi et al., 2011; RRID:IMSR_JAX:013044), Ai14
(Madisen et al., 2010; RRID:IMSR_JAX:007908), Prkcd-cre (Haubensak et al., 2010; RRID:IMSR_JAX:028437), and Rosa26-stop ${ }^{\text {flox }}$-tTA (Li et al., 2010) mice were described previously and were purchased from the Jackson Laboratory. All mice were bred onto C57BL/6J genetic background. The Som-cre;Ail4 mice, which were heterozygous for both the Cre allele and the Lox-Stop-Lox-tdTomato allele, were bred by crossing homozygous Som-cre mice with homozygous Ail4 reporter mice. Both male and female mice were used for the tracing and physiology experiments, but only male mice were used for the behavioral experiments. All procedures involving animals were approved by the Institute Animal Care and Use Committees of the Cold Spring Harbor Laboratory and performed in accordance with United States National Institutes of Health standards.

\section{Viral vectors}

Most of the following adeno-associated viruses (AAVs) were produced by the Vector Core at the University of North Carolina at Chapel Hill or the Penn Vector Core at the University of Pennsylvania and have previously been described (Ahrens et al., 2015; Penzo et al., 2015; StephensonJones et al., 2016; Yu et al., 2016): AAV9-Ef1a-DIO-eYFP (lot \#V4548MI-R), AAV9-Ef1a-DIO-hChR2(H134R)-eYFP (lot \#CS07543CS), AAV9-CAG-ChR2-GFP (lot \#AV4148c), AAV9.CAG.Flex.TeLCeGFP.WPRE.bGH (lot \#V5466S), AAV-TRE-hGFP-TVA-G (lot \#AV4656), and AAV9-FLEX-GFP (lot \#AV5220b). The AAV8.2-hEF1 $\alpha$ DIO-synaptophysin-mCherry $\left[2.5 \times 10^{13}\right.$ vector genomes $\left.(\mathrm{vg}) / \mathrm{ml}\right]$ was produced by the Massachusetts Institute of Technology Viral Gene Transfer Core. The EnvA-pseudotyped, protein-G-deleted rabies-EnvASAD- $\Delta$ G-mCherry virus $\left(5 \times 10^{8} \mathrm{vg} / \mathrm{ml}\right)$ was produced by the Viral Vector Core Facility at the Salk Institute (Penzo et al., 2015). CAV2-Cre $\left(9.9 \times 10^{12} \mathrm{vg} / \mathrm{ml}\right)$ was purchased from Montpellier vector platform (Plateforme de Vectorologie de Montpellier, Biocampus Montpellier, Montpellier, France; Penzo et al., 2015; Stephenson-Jones et al., 2016). All viral vectors were stored in aliquots at $-80^{\circ} \mathrm{C}$ until use.

\section{Histology}

Animals were deeply anesthetized and transcardially perfused with PBS, followed by perfusion with $4 \%$ paraformaldehyde (PFA) in PBS. Brains were dissected out and postfixed in $4 \% \mathrm{PFA}$ at $4^{\circ} \mathrm{C}$ for $3 \mathrm{~h}$ followed by cryoprotection in a PBS-buffered sucrose $(30 \%)$ solution until brains were saturated $(\sim 36 \mathrm{~h})$. Fifty-micrometer-thick coronal brain sections were cut on a freezing microtome (SM 2010R, Leica). Brain sections were first washed in PBS $(3 \times 5 \mathrm{~min})$ at room temperature $(\mathrm{RT})$ and then were blocked in $3 \%$ normal goat serum (NGS) in PBST $(0.3 \%$ Triton X-100) for $30 \mathrm{~min}$ at RT, followed by incubation with primary antibodies overnight at $4^{\circ} \mathrm{C}$. Sections were then washed with PBS $(4 \times 15 \mathrm{~min})$ and incubated with fluorescent secondary antibodies at RT for $2 \mathrm{~h}$. After washing with PBS $(4 \times 15 \mathrm{~min})$, sections were mounted onto glass slides with Fluoromount-G (Beckman Coulter). Images were taken using a LSM 780 laser-scanning confocal microscope (Carl Zeiss).

\section{Electrophysiology}

For electrophysiological experiments, mice were anesthetized with isoflurane and decapitated. Their brains were then quickly removed and chilled in ice-cold dissection buffer $(110.0 \mathrm{~mm}$ choline chloride, $25.0 \mathrm{~mm}$ $\mathrm{NaHCO}_{3}, 1.25 \mathrm{~mm} \mathrm{NaH}_{2} \mathrm{PO}_{4}, 2.5 \mathrm{~mm} \mathrm{KCl}, 0.5 \mathrm{~mm} \mathrm{CaCl}_{2}, 7.0 \mathrm{~mm} \mathrm{MgCl}_{2}$, $25.0 \mathrm{~mm}$ glucose, $11.6 \mathrm{~mm}$ ascorbic acid, and $3.1 \mathrm{~mm}$ pyruvic acid, gassed with $95 \% \mathrm{O}_{2}$ and $5 \% \mathrm{CO}_{2}$ ). Coronal slices ( $300 \mu \mathrm{m}$ thick) containing the amygdala complex were cut in dissection buffer using a HM650 Vibrating-Blade Microtome (Thermo Fisher Scientific). Slices were immediately transferred to a storage chamber containing artificial CSF (ACSF; $118 \mathrm{~mm} \mathrm{NaCl}, 2.5 \mathrm{~mm} \mathrm{KCl}, 26.2 \mathrm{~mm} \mathrm{NaHCO}_{3}, 1 \mathrm{~mm} \mathrm{NaH}_{2} \mathrm{PO}_{4}$, $20 \mathrm{~mm}$ glucose, $2 \mathrm{~mm} \mathrm{MgCl}_{2}$, and $2 \mathrm{~mm} \mathrm{CaCl}_{2}$, at $34^{\circ} \mathrm{C}$, pH 7.4, gassed with $95 \% \mathrm{O}_{2}$ and $5 \% \mathrm{CO}_{2}$ ). After $40 \mathrm{~min}$ recovery time, slices were transferred to RT $\left(20-24^{\circ} \mathrm{C}\right)$ and perfused with ACSF constantly.

Simultaneous whole-cell patch-clamp recordings from pairs of $\mathrm{SOM}^{+}$ and $\mathrm{SOM}^{-}$CeL neurons were obtained with Multiclamp 700B amplifiers (Molecular Devices). Recordings were guided visually using an Olympus BX51 microscope equipped with both transmitted light illumination and epifluorescence illumination, and $\mathrm{SOM}^{+}$cells were identified based on their fluorescence (tdTomato). To evoke IC-driven synaptic transmission onto CeL neurons, the AAV-ChR2-YFP was injected into the IC 
of Som-Cre;Ai14 mice and allowed to express for 3 weeks. Acute brain slices were prepared, and a blue light was used to stimulate ChR2expressing axons in the CeL. The light source was a single-wavelength LED system ( $\lambda=470 \mathrm{~nm}$; CoolLED) connected to the epifluorescence port of the Olympus BX51 microscope. Light pulses of $1 \mathrm{~ms}$ each were triggered by a transistor-transistor logic signal from the Clampex software to drive synaptic responses. Light pulses were delivered every $10 \mathrm{~s}$ and synaptic responses were low-pass filtered at $1 \mathrm{kHz}$ and recorded at holding potentials of $-70 \mathrm{mV}$ (for AMPA receptor-mediated responses) and $+40 \mathrm{mV}$ (for NMDA receptor-mediated responses). NMDA receptor-mediated responses were quantified as the mean current amplitude from 50 to $60 \mathrm{~ms}$ after stimulation. Evoked EPSCs were recorded in ACSF with $100 \mu \mathrm{M}$ picrotoxin to block inhibitory synaptic transmission. The internal solution for voltage-clamp experiments contained $115 \mathrm{~mm}$ cesium methanesulphonate, $20 \mathrm{~mm} \mathrm{CsCl,} 10 \mathrm{~mm}$ HEPES, $2.5 \mathrm{~mm} \mathrm{MgCl}_{2}$, $4 \mathrm{~mm} \mathrm{Na}_{2}$-ATP, $0.4 \mathrm{~mm} \mathrm{Na}_{3} \mathrm{GTP}, 10 \mathrm{~mm} \mathrm{Na}$-phosphocreatine, and 0.6 mм EGTA, pH 7.2. To assess presynaptic function, a paired-pulse stimulation protocol (50 ms interstimulus interval) was used to evoke double EPSCs, and paired-pulse ratio (PPR) was quantified as the ratio of the peak amplitude of the second EPSC to that of the first EPSC.

\section{Monosynaptic tracing with pseudotyped rabies virus}

Retrograde tracing of monosynaptic inputs onto genetically defined cell populations of CeL was performed and described in our previous study (Penzo et al., 2015), and the data presented here were generated from the same study but were not published previously. Briefly, the Som-cre; Rosa26-stop ${ }^{\text {flox }}$-tTA mice and the Prkcd-cre;Rosa26-stof ${ }^{\text {flox }}$-tTA mice, which express tetracycline transactivator (tTA) in $\mathrm{SOM}^{+}$cells and $\mathrm{PKC}-\delta^{+}$cells, respectively, were injected into the CeL with the AAVTRE-hGFP-TVA-G $(0.2-0.3 \mu \mathrm{l})$ that expresses the following components in a tTA-dependent manner: a fluorescent reporter histone GFP (hGFP); TVA (avian tumor receptor A; which is a receptor for the avian virus envelope protein EnvA); and the rabies envelope glycoprotein (G). Two weeks later the mice were injected in the same location with the rabies-EnvA-SAD- $\Delta$ G-mCherry $(1.2 \mu \mathrm{l})$, a rabies virus that is pseudotyped with EnvA, lacks the envelope glycoprotein, and expresses mCherry. This method ensures that the rabies virus exclusively infects cells expressing TVA. Furthermore, complementation of the modified rabies virus with envelope glycoprotein in the TVA-expressing cells allows the generation of infectious particles, which then can transsynaptically infect presynaptic neurons.

\section{Stereotaxic surgery}

Standard surgical procedures were followed for stereotaxic injection ( $\mathrm{Li}$ et al., 2013; Penzo et al., 2015). Briefly, mice were anesthetized with ketamine (100 mg per kg of body weight) supplemented with dexmedetomidine hydrochloride $(0.4 \mathrm{mg}$ per $\mathrm{kg})$ and positioned in a stereotaxic injection frame (myNeuroLab, Leica Biosystems). A digital mouse brain atlas was linked to the injection frame to guide the identification and targeting (Angle Two Stereotaxic System, Leica Biosystems).

Viruses $(\sim 0.4 \mu \mathrm{l})$ were delivered with a glass micropipette (tip diameter, $\sim 5 \mu \mathrm{m})$ through a skull window $\left(1-2 \mathrm{~mm}^{2}\right)$ by pressure applications $(5-20 \mathrm{psi}, 5-20 \mathrm{~ms}$ at $0.5 \mathrm{~Hz})$ controlled by a Picrospritzer III (General Valve) and a pulse generator (Agilent). The injection was performed at the following stereotaxic coordinates: for CeL: $1.18 \mathrm{~mm}$ posterior, $2.9 \mathrm{~mm}$ lateral, and $4.6 \mathrm{~mm}$ ventral from bregma; for IC: $0.10 \mathrm{~mm}$ posterior, $3.90 \mathrm{~mm}$ lateral, and $4.20 \mathrm{~mm}$ ventral from bregma. For optogenetic experiments, immediately after viral injection, an optical fiber (core diameter, $105 \mu \mathrm{m}$; Thorlabs, catalog \#FG105UCA) was implanted $300 \mu \mathrm{m}$ above the center of viral injection. The optical fiber together with the ferrule (Thorlabs) was secured to the skull with C\&B-Metabond Quick adhesive luting cement (Parkell), followed by dental cement (Lang Dental Manufacturing).

Following the above procedures, a small metal bar was mounted on the skull, which was used to hold the mouse in the head fixation frame during behavior experiments.

\section{Behavioral tasks}

Licking behavior. Water deprivation started $23 \mathrm{~h}$ before training. Mice were trained in the head-fixation frame for 10 min daily. A metal spout was placed in front of the animal's mouth for water delivery. The spout also served as part of a custom "lickometer" circuit, which registered a lick event each time a mouse completed the circuit by licking the spout while standing on a metal floor. The lick events were recorded by a computer through custom software written in LabView (National Instruments). Each lick triggered a single opening of a water valve calibrated to deliver $0.3 \mu \mathrm{l}$ of water.

It took mice $4-7 \mathrm{~d}$ to achieve stable licking, the criterion for which was 10 min continuous licking with no interval between licking $>10 \mathrm{~s}$. We used a lick-suppression index to quantify animals' degree of photostimulation-evoked suppression of licking behavior. The formula for that index was as follows: $\left(L_{\mathrm{PRE}}-L_{\mathrm{CS}}\right) /\left(L_{\mathrm{PRE}}+L_{\mathrm{CS}}\right)$, where $L_{\mathrm{PRE}}$ is the number of licks in the $5 \mathrm{~s}$ period before CS onset, and $L_{\mathrm{CS}}$ is the number of licks in the $5 \mathrm{~s}$ CS period (Yu et al., 2016).

Go/no-go task. Water deprivation started $23 \mathrm{~h}$ before training, and mice were habituated to the head-fixation frame for $20 \mathrm{~min}$ on the first day of training with access to water through the metal spout. On following days, animals underwent two training sessions each day, one in the morning and the other in the afternoon. The two sessions were $\geq 4 \mathrm{~h}$ apart, with each consisting of 100 trials. For the subsequent 3-6 sessions, mice were exposed only to the "go" cue (a $1 \mathrm{~s}, 5 \mathrm{kHz}$ pure tone) followed by the delivery of $4.5 \mu \mathrm{l}$ of water. After mice successfully retrieved water on $\geq 80 \%$ of the trials, they moved to the next training phase, in which they were required to lick the spout $\geq 1$ time during the go cue in order for the water to be released. This phase took an additional 3-6 sessions until the animals reached the criteria of $80 \%$ correct responses. Following this phase, animals received one training session consisting of the go cue paired with the delivery of sucrose solution $(100 \mathrm{~mm})$ instead of water.

The next phase consisted of 10 sessions of go/no-go training. During this phase, 50 presentations of the go cue were delivered randomly intermixed with 50 presentations of the no-go cue (a $1 \mathrm{~s}$ white noise), with the constraint that either cue could not appear $>5$ times in a row, and that the first trial was always a go cue. Licking the spout during the no-go cue resulted in the delivery of quinine solution $(4.5 \mu \mathrm{l}, 5 \mathrm{~mm})$. The mice were required to lick the spout at least once during the $1 \mathrm{~s}$ window of cue presentation to receive the US. During all phases of the experiment, brief suction (500 $\mathrm{ms}$ in duration) near the spout was applied $3.5 \mathrm{~s}$ after tone onset to remove any residual solution from the previous trial.

For analysis, trials were sorted into go trials and no-go trials. A correct response during a go trial ("hit") occurred when the mouse successfully licked the spout during the go cue and subsequently received sucrose. A correct response during a no-go trial ("correct reject") occurred when the mouse successfully omitted the lick response during the no-go cue and thus avoided quinine. The overall performance over the entire session was calculated as the total correct responses divided by the total trials: (hits + correct rejects)/(total trials). To measure intertrial interval licking $\left(L_{\mathrm{ITI}}\right)$, we analyzed lick rate during the $1 \mathrm{~s}$ time window immediately preceding each CS. This measurement was also used to compute the "licking index" as a measure of the CS-evoked licking: $\left(L_{\mathrm{CS}}-L_{\mathrm{ITI}}\right)$ / $\left(L_{\mathrm{CS}}+L_{\mathrm{ITI}}\right)$, where $L_{\mathrm{CS}}$ is the lick rate during the $1 \mathrm{~s}$ CS presentation.

For the optogenetics experiments, we used a modified version of this go/no-go task, in which licking during the go cue led to water delivery $(4.5 \mu \mathrm{l})$, whereas licking during the no-go cue resulted in water delivery $(4.5 \mu \mathrm{l})$ accompanied by laser stimulation. The laser was delivered coincidentally with water delivery (50 ms after CS offset) at 20 or $30 \mathrm{~Hz}$ for $2.5 \mathrm{~s}$ (the period water would be available if the animal licked during the no-go cue presentation). Suction was applied to remove any unconsumed water. Animals received eight training sessions in the final phase of this task.

Real-time place aversion. As previously described (Stephenson-Jones et al., 2016), one side of a custom chamber $(23 \times 33 \times 25 \mathrm{~cm}$; made from Plexiglas) was assigned as the stimulation zone, counterbalanced among mice. Mice were placed individually in the middle of the chamber at the onset of the experiment, which lasted $30 \mathrm{~min}$. Laser stimulation $(5 \mathrm{~ms}$ pulses delivered at 20 or $30 \mathrm{~Hz}$ ) was triggered when mice entered the stimulation zone, and lasted until mice exited the stimulation zone. Mice were videotaped with a CCD camera interfaced with the Ethovision software (Noldus Information Technologies), which was used to control the 
laser stimulation and extract the behavioral parameters (position, time, distance, and velocity).

In vivo optogenetics. For bilateral optogenetic stimulation in the CeL, a branched patch-cord (Doric Lenses, catalog \#BFP(2)_105/125/900$\left.0.22 \_1 \mathrm{~m} \_F C-2 x Z F 1.25\right)$ for light delivery was connected at one end to a laser source ( $\lambda=473 \mathrm{~nm}$; OEM Laser Systems) and at the other end, which was composed of two terminals, to two CeL-implanted optical fibers through sleeves (Thorlabs). For photostimulation-induced lick suppression, the stimuli were $5 \mathrm{~ms}, 30 \mathrm{~Hz}$ light pulses (or across a range of frequencies) delivered for $5 \mathrm{~s}$. For photostimulation during real-time place aversion (RTPA), $5 \mathrm{~ms}, 20$ or $30 \mathrm{~Hz}$ light pulses were delivered. Laser intensity was $10 \mathrm{~mW}$ measured at the end of optical fiber.

\section{Experimental design and statistical analysis}

All data are presented as mean \pm SEM. All statistics are indicated where used. Data were analyzed with GraphPad Prism. Behavioral tests were performed by an investigator with knowledge of the identity of the experimental groups. All behavior experiments were controlled by computer systems, and data were collected and analyzed in an automated and unbiased way. Virus-injected animals in which the injection or optical fiber implantation was misplaced were excluded.

Electrophysiology experiments were conducted on male and female mice ( $n=3$ male, 3 female) $35-45$ d old. Data were analyzed using a two-tailed unpaired $t$ test.

Go/no-go behavioral experiments and quinine sensitivity tests were performed with the same set of male mice, ranging in age from 40 to $80 \mathrm{~d}$. Behavioral experiments were performed during the light cycle. For the GFP control group, $n=9$ mice; for the tetanus toxin light chain (TeLC) group, $n=7$ mice. The quinine sensitivity test was performed with a subset of these males (GFP, $n=8$; TeLC, $n=6$ ). For comparisons between groups (main effect of treatment) over the 10 training sessions (main effect of session), data were analyzed with a two-way repeatedmeasures (RM) ANOVA followed, for significant differences, by post hoc Sidak's multiple-comparisons tests to examine the difference between the GFP and TeLC groups for each session.

Lick suppression behavioral experiments were performed with male mice. For the GFP control group, $n=4$ mice; for the ChR2 group for 30 $\mathrm{Hz}, n=6$ mice; for the ChR2 group for $5-20 \mathrm{~Hz}, n=3$ mice. Data were analyzed with a one-way ANOVA followed by post hoc Sidak's multiplecomparisons tests to examine the difference between the GFP and ChR2 groups. The RTPA test was conducted with these same animals (GFP, $n=4$ mice; ChR2, $n=6$ mice). Data were analyzed with a two-way RM ANOVA for comparisons between groups (main effect of treatment) and stimulation side (left vs right) followed by a Sidak's multiplecomparisons test. The modified go/no-go test was also performed with a subset of these animals (GFP, $n=4$ mice; ChR2, $n=5$ mice). For comparisons between groups (main effect of treatment) over the 10 training sessions (main effect of session), data were analyzed with a twoway RM ANOVA followed, for significant differences, by post hoc Sidak's multiple-comparisons tests to examine the difference between the GFP and ChR2 groups for each session. Post hoc Dunnett's tests were used to compare behavioral responses in different sessions to those in Session 1 to examine learning effects across time.

\section{Results}

To investigate the function of the IC-CeL circuit, we began by characterizing how IC neurons innervate the major CeL cell types. We first used a modified rabies virus system to trace the monosynaptic inputs onto CeL neurons (Callaway and Luo, 2015; Penzo et al., 2015). This approach revealed a monosynaptic projection from the IC to the CeL (Fig. $1 A, B$ ), with IC neurons innervating both of the two major populations of the CeL, the $\mathrm{SOM}^{+}$neurons and PKC- $\delta^{+}$neurons (Fig. $1 A, B$ ). Notably, the IC was the only cortical region identified by this approach to send monosynaptic projections to the CeL. The CeL-projecting IC neurons were preferentially localized in the posterior part of the IC, which overlaps at least partially with the GC (Fig. 1B), which is consistent with previous findings based on classical tracing methods (Allen et al., 1991; McDonald, 1998).

As the IC also sends projections to the BLA (Allen et al., 1991; McDonald, 1998), we next determined whether the same IC neurons project to both the CeL and the BLA. To this end, we injected the CeL and BLA with the retrograde tracer AlexaFluor-488conjugated or AlexaFluor-555-conjugated cholera toxin (CTB488 or CTB-555), respectively (Fig. $1 C$ ). We found that CTB reliably labeled CeL-projecting IC neurons (Fig. $1 D$ ) with a distribution pattern similar to that of CeL-projecting IC neurons labeled by the rabies virus (Fig. $1 B$ ). CTB also labeled a prominent population of BLA-projecting IC neurons, the vast majority of which has a distribution pattern distinct from that of CeLprojecting IC neurons (Fig. 1D). This result demonstrates that CeL-projecting neurons and BLA-projecting neurons in the IC are largely nonoverlapping populations.

To selectively target the CeL-projecting IC neurons and visualize their axonal projections, we injected the CeL with a retrograde canine adenovirus expressing Cre recombinase (CAV2-Cre; Bru et al., 2010), followed by injecting the IC with an AAV harboring a double-floxed inverted open reading frame (AAV-DIO) that expresses, in a Cre-dependent manner, a presynaptic protein synaptophysin tagged with a fluorescent protein mCherry (AAV-DIO-synaptophysin-mCherry; Fig. 1E). This strategy led to the labeling of IC neurons that sent dense axonal fibers to the CeL (Fig. 1F). Sparse labeling of axon fibers in the BLA can also be detected (Fig. $1 F$ ), which likely was caused by spillover of the CAV2-Cre to the BLA and thus the labeling of BLA-projecting IC neurons. Though the ipsilateral CeL had the densest projections, we also observed $\mathrm{mCherry}^{+}$axon terminals in the contralateral $\mathrm{CeL}$, which is consistent with results from retrograde tracing with CTB (data not shown). Altogether, the anatomical tracing results demonstrate that the IC sends robust monosynaptic projections to $\mathrm{SOM}^{+}$and $\mathrm{PKC}-\delta^{+} \mathrm{CeL}$ neurons, and that the IC-CeL circuit and the IC-BLA circuit are distinct from one another.

To assess the synaptic connectivity between the IC and CeL, we used the Som-cre;Ail4 mice, in which $\mathrm{SOM}^{+}$cells can be identified by their red fluorescence, and injected the IC of these mice with an AAV expressing the light-gated cation channel channelrodhopsin-2 (AAV-ChR2-YFP), which allows photostimulation of axonal projections (Zhang et al., 2006; Fig. 2A). Approximately 3 weeks after the AAV injection, we prepared from these mice acute brain slices containing the CeL, in which we recorded synaptic transmission onto simultaneously patched pairs of adjacent $\mathrm{SOM}^{+}$(red fluorescent) and $\mathrm{SOM}^{-}$(nonfluorescent) CeL neurons in response to optogenetic stimulation of the IC inputs. Brief light pulses evoked fast excitatory synaptic transmission in nearly all the recorded CeL neurons (Fig. 2B; $\sim 95 \%$ of the recorded neurons, including both $\mathrm{SOM}^{+}$or $\mathrm{SOM}^{-}$, responded to the light stimulation). Notably, the AMPA receptor-mediated component of synaptic transmission onto $\mathrm{SOM}^{+}$neurons was significantly greater than that onto SOM${ }^{-}$ neurons (Fig. $2 B, C ; t_{(18)}=3, p=0.0085, t$ test). The NMDA receptor-mediated synaptic transmission onto these two neuronal populations was not different $\left(t_{(18)}=0.7, p=0.47, t\right.$ test). In a subset of these pairs, we also examined the PPR (see Materials and Methods) and found no significant difference between the two cell types (Fig. $2 C ; t_{(12)}=1.8, p=0.1, t$ test). These results indicate that IC inputs can activate both $\mathrm{SOM}^{+}$neurons and $\mathrm{SOM}^{-}$neurons in the $\mathrm{CeL}$, with the latter being mainly $\mathrm{PKC}-\delta^{+}$ neurons (Li et al., 2013). 
A

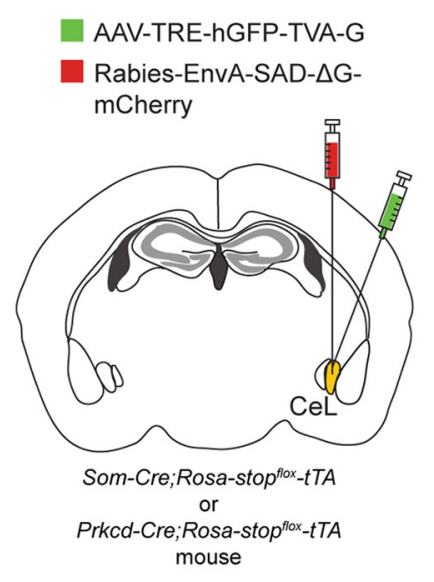

AAV-TRE-hGFP-TVA-G

Rabies-EnvA-SAD- $\triangle$ GmCherry

B
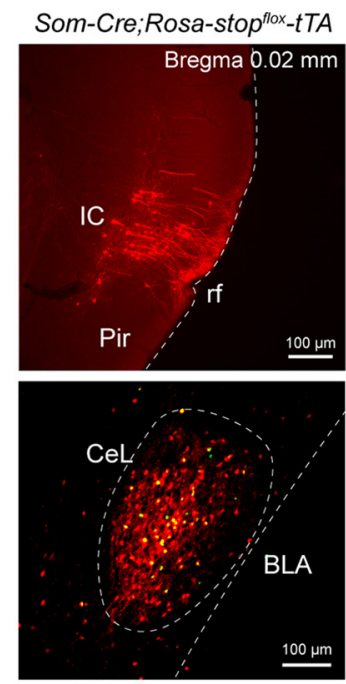

D
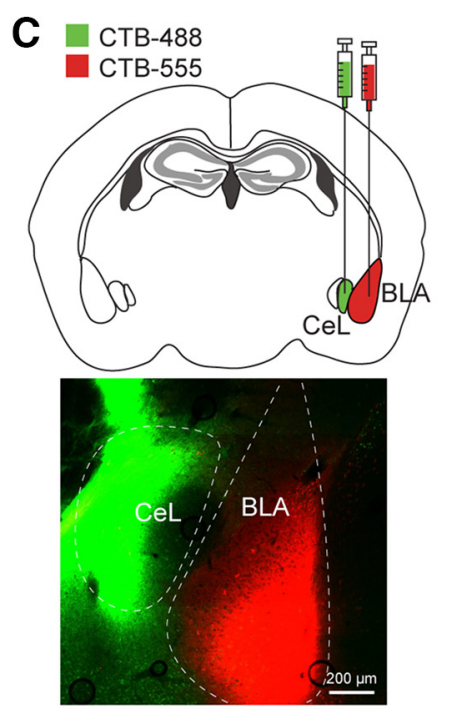
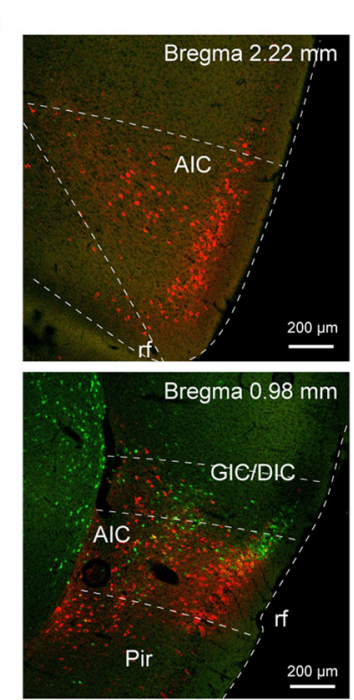

Prkcd-Cre:Rosa-stop $p^{\text {flox }}$-tTA
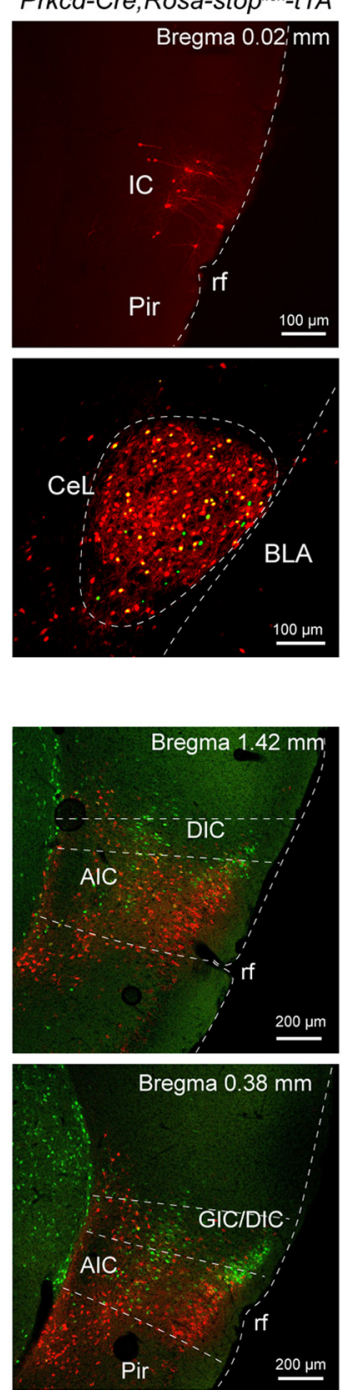

\section{E}

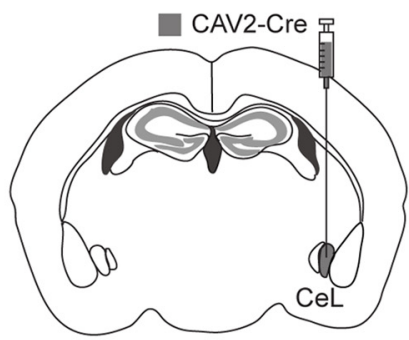

AAV-DIO-synaptophysin-

mCherry

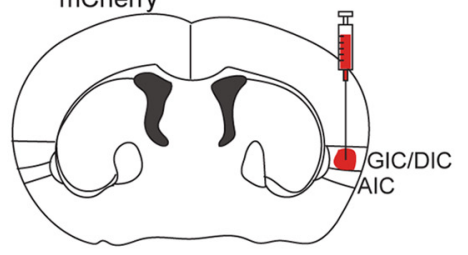

$\mathbf{F}$
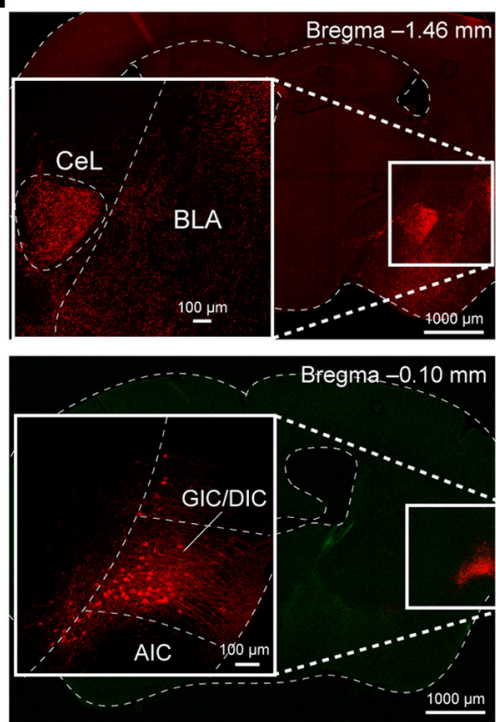

Figure 1. The IC sends monosynaptic projections to the amygdala. $\boldsymbol{A}$, A schematic of the experimental approach (see Materials and Methods). $\boldsymbol{B}$, Representative images of the tracing result for $\mathrm{SOM}^{+}$(left) and PKC- $\delta^{+}$(right) CeL neurons. Top, Retrogradely labeled neurons in the IC. Bottom, Starter neurons in the CeL are identified by their coexpression of mCherry and hGFP (cells in yellow). Data in $\boldsymbol{A}$ and $\boldsymbol{B}$ were replicated in three mice for each group, and were from the same injections reported in Penzo et al. (2015). C, Top, Schematic of the experimental approach. Bottom, Representative image of the injection sites. D, The distribution of the BLA-projecting (red) and the CeL-projecting (green) neurons in the IC. AIC, Agranular insular cortex; GIC, granular insular cortex; DIC, dysgranular insular cortex. Data in $\boldsymbol{C}$ and $\boldsymbol{D}$ were replicated in two mice. $\boldsymbol{E}$, A schematic of the experimental approach. $\boldsymbol{F}$, Representative images showing the $\mathrm{mCherry}{ }^{+}$axons (top), which originated from the CeL-projecting IC neurons (bottom). In the insets are enlarged images of the boxed areas in the right, which are located in the amygdala (top) and the IC (bottom).

To investigate the behavioral role of the IC-CeL circuit, we set out to inhibit the CeL-projecting IC neurons in mice and subsequently trained these mice in a tastant-reinforced go/no-go task that engages the IC. We first injected the CeL with the CAV2-Cre (Fig. $3 A$ ), and then injected the IC in the same mice with an AAV expressing the TeLC, which blocks neurotransmitter release (Murray et al., 2011), or GFP (as a control) in a Cre-dependent manner (AAV-DIO-TeLC-GFP or AAV-DIO-GFP, respectively; Fig. $3 A$ ). As described above (Fig. $1 E, F$ ), this strategy led to selective targeting of the IC-CeL circuit (Fig. $3 B, C$ ).

Four to 5 weeks following viral injections, we began training these mice in the go/no-go task (see Materials and Methods), in which an auditory stimulus (go cue) predicts the delivery of a palatable liquid (sucrose), while a different auditory stimulus (no-go cue) predicts the delivery of an unpleasant liquid (quinine; Fig. 3D). Mice need to learn to produce an instrumental response (lick) during the go cue to receive sucrose, and inhibit that response during the no-go cue to avoid quinine (Fig. $4 A$ ).
Learning in similar tasks has previously been shown to be paralleled by the development of cue-specific responses in IC neurons (Gardner and Fontanini, 2014; Livneh et al., 2017).

We found that bilateral inhibition of synaptic transmission from the CeL-projecting IC neurons with TeLC markedly affected animals' behavior in the go/no-go task (Fig. 4). Specifically, in the go trials, although mice in both the GFP group and the TeLC group showed stimulus-evoked licking (Fig. 4A) and had similar performance (Fig. 4B), closer inspection of these animals' behavioral patterns revealed that the TeLC mice did not allocate their licking to the CS and US period to the same degree as the GFP control mice, especially on the final training session (Session 10; Fig. 4A). Indeed, when we analyzed the CS-evoked licking rate during the go cue normalized to the baseline licking rate for each trial ("licking index"; see Materials and Methods), we found that the TeLC mice showed marked impairment in the development of CS-evoked licking compared with the GFP mice (Fig. $4 C, E$; main effect of treatment, $F_{(1,14)}=15.1, p=0.0016$; 
A
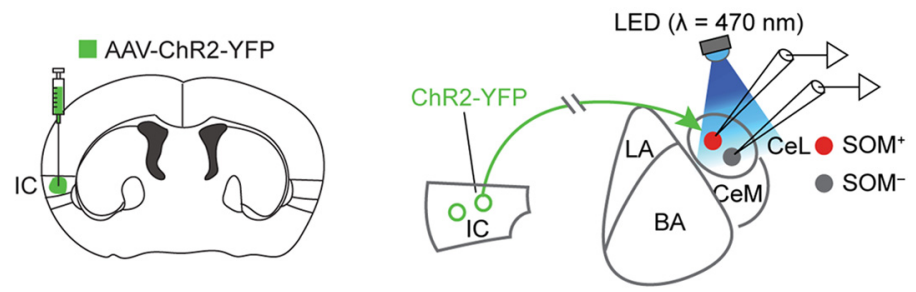

B
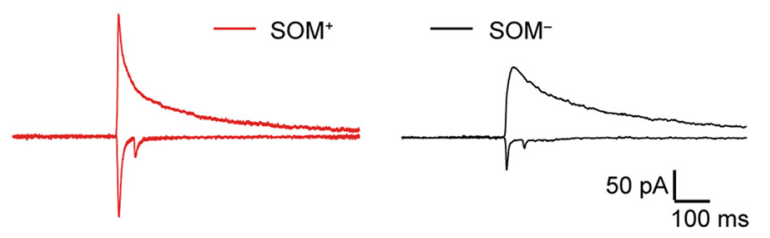

C
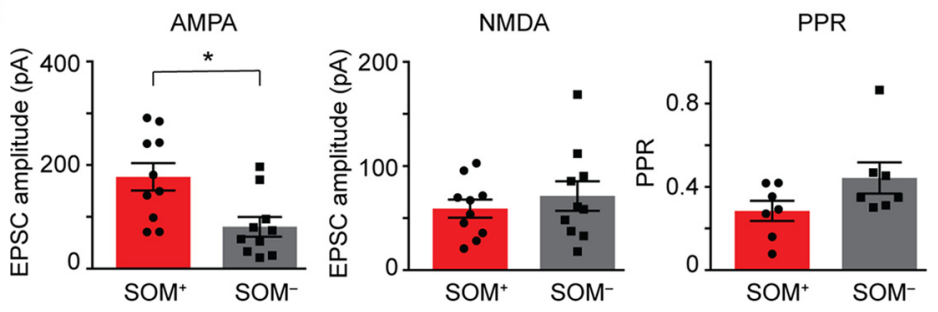

Figure 2. Functional connectivity between IC neurons and CeL neurons. A, A schematic of the experimental design. AAV-ChR2YFP was injected into the IC of a SOM;Ai14 mouse (left), and patch-clamp recording was performed in acute slices containing the amygdala (right). $\boldsymbol{B}$, Sample traces of EPSCs recorded from a SOM ${ }^{+}$and a SOM ${ }^{-}$CeL neuron, which were recorded simultaneously. The EPSCs were evoked by optogenetic stimulation of the IC axons terminating in the CeL, with the AMPA receptor-mediated EPSCs being stimulated with two pulses ( 50 ms interpulse interval) protocol. C, Quantification of the EPSC amplitude evoked by the first pulse mediated by AMPA receptors is shown in the left panel, NMDA receptors are shown in the middle, and the PPR of AMPA receptor-mediated EPSC s is shown on the right. ${ }^{*} p=0.0085$, for AMPA and NMDA, $n=10$ pairs; for PPR, $n=7$ pairs. Data in $C$ are presented as mean \pm SEM.

main effect of session, $F_{(9,126)}=4.246, p<0.0001$; interaction, $F_{(9,126)}=1.832 ; p=0.0686$; two-way RM ANOVA). Post hoc tests revealed significant differences between GFP and TeLC groups (Fig. $4 C$; ${ }^{\star} p<0.05$ in Sessions 1,2 , and 4 ; ${ }^{\star} p<0.01$ in Sessions $5-10)$. Despite the impairment in licking to the CS in the TeLC mice, we noted evidence of learning in both groups of mice. Post hoc Dunnett's tests were run within each group to compare CSevoked licking during Session 1 against following sessions. The GFP mice increased their licking in Sessions $6-10(p<0.05)$ while the TeLC mice increased their licking only in Session 10 $(p<0.05)$.

Of note, the effect of learning in the go trials (Fig. $4 B, C$ ) is underestimated as mice had already been well trained to associate the go cue with water or sucrose delivery before the first session of the go/no-go task (see Materials and Methods). Nonetheless, in addition to the licking response, TeLC mice's performance was also impaired compared with the GFP mice (Fig. $4 B$ ), but this impairment was mild and was only detected in Session 8 (significant interaction between treatment and session, $F_{(9,126)}=2.824$; $p=0.0047$; post hoc test for Session 8, $p=0.0055$; two-way RM ANOVA). These results indicate that the TeLC manipulation impaired performance and acquisition of the go trials.

In the no-go trials, the GFP mice gradually learned to withhold licking in response to the no-go cue, and thus successfully avoided quinine in most of the trials toward the end of the training sessions (Fig. 4A-C). By contrast, the TeLC mice showed no sign of learning and thus were markedly impaired in performance even at the end of the training sessions [Fig. $4 A, B$; main effect of session, $F_{(9,126)}=2.84, p=0.0045$; main effect of treatment, $F_{(1,14)}=17.56, p=0.0009$; interaction, $F_{(9,126)}=4.8, p<0.0001$, two-way RM ANOVA; post hoc tests were significant for Sessions 4-10 (Session 4, ${ }^{\star} p=0.0139$; Sessions $\left.5-10,{ }^{\star} p<0.005\right)$ compared with the GFP group]. When combining the go and no-go trials, the overall performance of the TeLC mice was also impaired [Fig. $4 B$; main effect of session, $F_{(9,126)}=2.41, p=0.0149$; main effect of treatment, $F_{(1,14)}=24.28, p=$ 0.0002 ; interaction, $F_{(9,126)}=9.8, p<$ 0.0001, two-way RM ANOVA; post hoc tests were significant $\left({ }^{*} p<0.002\right)$ in Sessions $4-10$ ]. Furthermore, we found that while the GFP group gradually learned to suppress licking (as measured by the licking index; see Materials and Methods) in response to the CS predicting quinine, the TeLC mice were unable to do so (Fig. $4 C$; main effect of treatment, $F_{(1,14)}=8.581, p=0.0110$; main effect of session, $F_{(9,126)}=2.334, p=0.0182$; interaction, $F_{(9,126)}=4.42, p<0.0001$, two-way RM ANOVA; post hoc tests revealed significant differences between GFP and TeLC in Sessions 7 and $9\left({ }^{*} p<\right.$ $0.05)]$. In contrast to the go trials, we noted in this licking index measurement that the GFP control mice displayed clear learning to the no-go cue, decreasing their licking in Sessions 4 and 6-10 compared to Session 1 (post hoc tests, $p<0.005$ ), whereas the TeLC mice showed no sign of learning $(p>0.4)$ in all sessions. These findings indicate that the TeLC manipulation blocked performance and acquisition of no-go trials. Overall, inhibition of the IC-CeL pathway caused impairments in behavioral responses in both the go and the no-go trials of the go/no-go task.

The impairment in behavioral inhibition observed during the no-go trials in the TeLC mice could be caused by a general increase in responding. However, we believe this is not the case as both the performance and CS-induced licking in the go trials were reduced, as described above. In addition, the TeLC mice showed lick rate similar to that of the GFP mice following the delivery of sucrose (Fig. $4 A, D$ ), further arguing against a general increase in responding in these mice. In contrast, these mice showed an increased lick rate during the intertrial interval (ITI; main effect of session, $F_{(9,126)}=4.13, p<0.001$; main effect of treatment, $F_{(1,14)}=15.73, p=0.001$; interaction, $F_{(9,126)}=2.08$, $p=0.037$, two-way RM ANOVA; post hoc tests ${ }^{*} p<0.05$ for Sessions 1, 3-7, 9; Fig. 4A,E), consistent with the notion that they were impaired in action suppression. We noticed that the TeLC mice showed an increased lick rate following quinine delivery compared with the GFP mice [main effect of treatment, $F_{(1,14)}=$ $6.329, p=0.0247$; main effect of session, $F_{(9,126)}=0.5082, p=$ 0.8664 ; interaction, $F_{(9,126)}=0.5194, p=0.8583$, two-way RM ANOVA; however, no individual session reached statistical significance in post hoc tests ( $p>0.35$ for all sessions); Fig. $4 D]$, suggesting that inhibiting the $\mathrm{IC}-\mathrm{CeL}$ pathway may partially impair the processing of aversive taste information during this task. However, we also tested a subset of these animals on their sensitivity to increasing concentrations of quinine during a freelicking session lasting $10 \mathrm{~min}$. Similar to the GFP control group, the TeLC group showed decreased average licking rate during this 
A
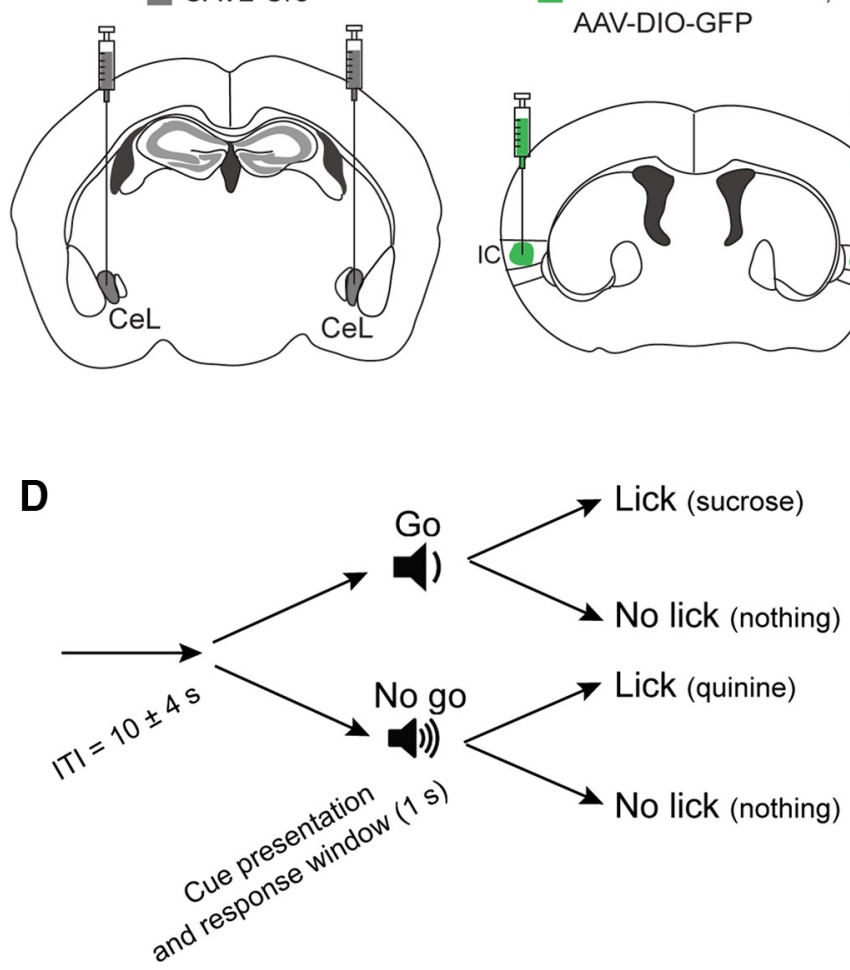

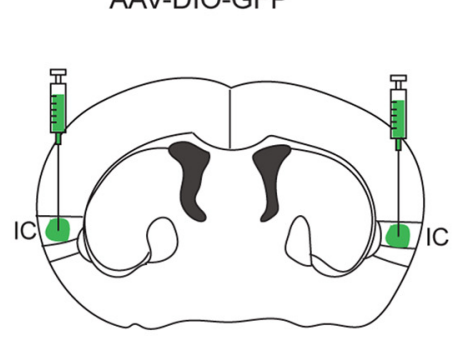

AAV-DIO-TeLC-GFP, or AAV-DIO-GFP

Lick (sucrose)
B
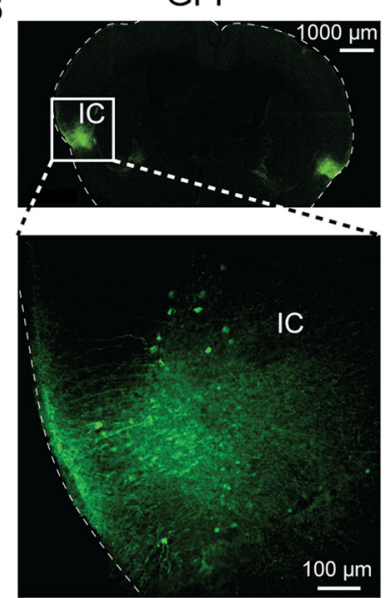

C

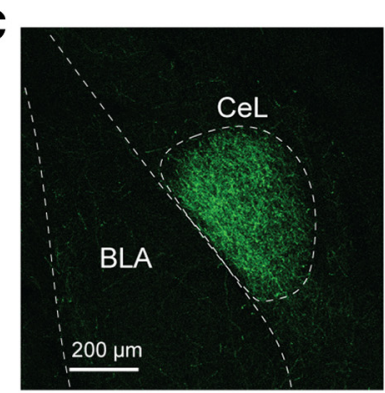

TeLC-GFP
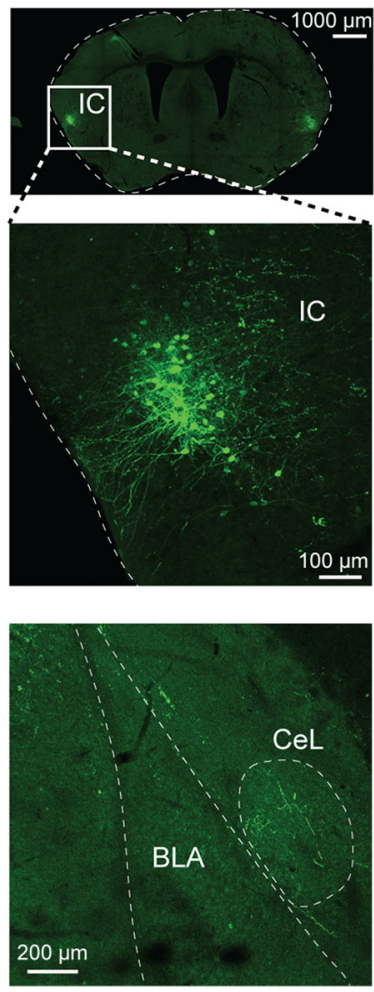

Figure 3. Experimental design to test the role of the IC-CeL circuit in a go/no-go task. $\boldsymbol{A}$, A schematic of the experimental design to selectively inhibit the IC-CeL circuit. $\boldsymbol{B}$, Representative images showing the cells in the IC infected with GFP (left) and TeLC-GFP (right) virus. In the lower panel are enlarged images of the boxed areas in the images in the upper panel. $\boldsymbol{C}$, Axon terminals expressing GFP (left) or TeLC-GFP (right), which originated from CeL-projecting IC neurons. D, A schematic of the go/no-go task.

period (reflecting a reduction in the total volume consumed) with increasing concentrations of quinine (main effect of quinine concentration, $F_{(7,84)}=16.3, p<0.0001$; main effect of treatment, $F_{(1,12)}=0.78, p=0.4$; interaction, $F_{(7,84)}=0.24, p=0.97$; two-way RM ANOVA; Fig. $4 F$ ). This result is consistent with previous findings that lesions of the GC in rats do not affect the amount of either quinine or sucrose solutions consumed at varying concentrations (Hashimoto and Spector, 2014), and indicates that inhibition of CeL-projecting IC neurons does not abolish animals' basic ability to process quinine's sensory and aversive properties, at least when there is little cognitive demand. Together, these results indicate that the IC-CeL pathway is required for establishing the learned, anticipatory responses reinforced by tastants.

To test whether activation of the IC-CeL pathway is sufficient to influence behavior, we delivered the ChR2 or GFP (as a control) specifically into CeL-projecting IC neurons bilaterally, using the retrograde and intersectional strategy based on CAV2-Cre as described above (Fig. 5A), and subsequently bilaterally implanted optical fibers over the CeL (Fig. $5 B, C$ ). Four to 5 weeks following surgery, these mice were water deprived and trained to achieve stable licking to a water spout, during which we delivered pulses of blue light into the CeL. Photostimulation in the CeL, in which the axon terminals originating from the IC expressed ChR2, elicited robust suppression of licking, an effect that was dependent on the frequency of stimulation [Fig. $5 D, E ; F_{(4,14)}=4.375, p=$ 0.017 , one-way ANOVA; post hoc tests revealed significant differences between GFP and ChR2 for $20(p=0.0065)$ and $30 \mathrm{~Hz}(p=$ $0.0109)$ stimulation]. Furthermore, such optogenetic activation of the IC-CeL pathway induced place aversion in an RTPA task [Fig. $5 F$; main effect of stimulation side, $F_{(2,16)}=4.27 ; p=0.03$; main effect of treatment, $F_{(1,8)}=1.53 ; p=0.25$; interaction, $F_{(2,16)}=6.94 ; p=0.007$, two-way RM ANOVA; post hoc tests revealed a significant difference between GFP and ChR2 mice when stimulated in the right side of the chamber $(p=0.0052)]$. By contrast, photostimulation in the CeL in which IC axons expressed GFP induced neither lick suppression nor place aversion (Fig. 5D-F). These results suggest that activation of the IC-CeL circuit is intrinsically aversive and sufficient to induce action suppression and avoidance responses.

To test whether activation of the IC-CeL circuit can be substituted for an aversive tastant to instruct avoidance learning, similar to learning of the no-go response in the go/no-go task, we trained the same mice as those used in Figure 5 in a modified go/no-go task, in which licking during one cue led to water delivery alone (the "laser-off" trials), whereas licking during another cue resulted in water delivery coinciding with bilateral photostimulation in the CeL (the "laser-on" trials; Fig. 6A; see Materials and Methods). We found that the mice in which the IC-CeL pathway expressed ChR2 - and thus could be activated by the photostimulation - showed reduced probability of licking during a trial (defined as a "chosen trial"; see Materials and Methods) compared with the GFP control mice in both the laser-off and the laser-on trials, although the reduction was more robust in the laser-on trials (Fig. 6B; laser off: main effect of treatment, $F_{(1,53)}=23.17, p<0.0001$; main effect of session, $F_{(7,53)}=$ $0.8625, p=0.5420$; interaction, $F_{(7,53)}=0.3526, p=0.9253$, no individual session reached significant in post hoc tests; laser on: two-way ANOVA main effect of treatment, $F_{(1,53)}=45.76, p<$ 0.0001 ; main effect of session, $F_{(7,53)}=0.8759, p=0.5317$; interaction, $F_{(7,53)}=0.4072, p=0.8937$, post hoc tests, ${ }^{*} p<0.05$ for Sessions 3 and 7). Consistently, in the final training session, the 
A

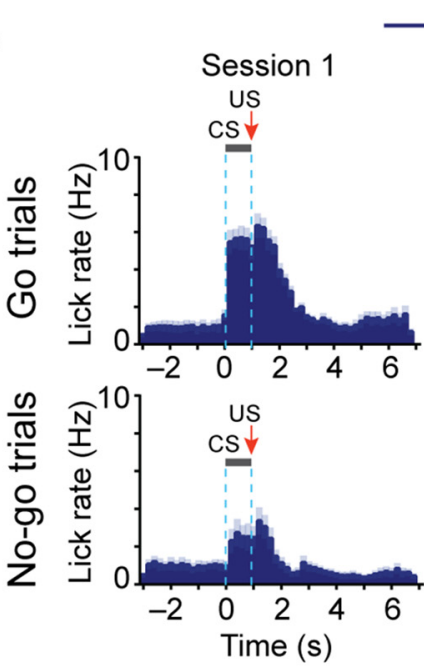

B

Go trials

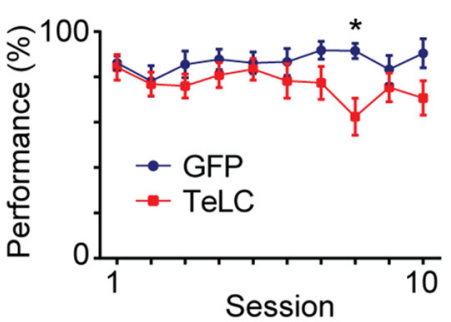

C

Go trials

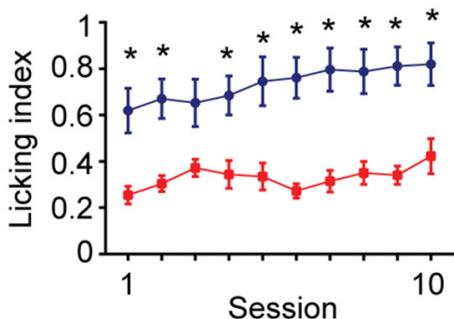

D

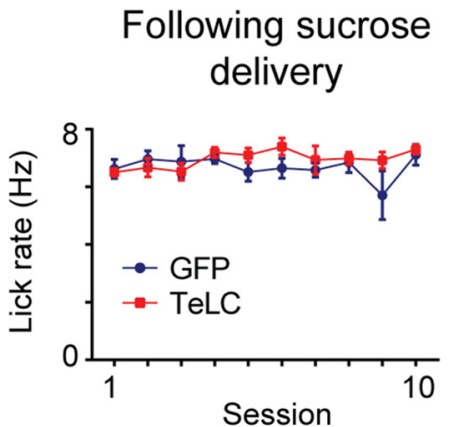

GFP
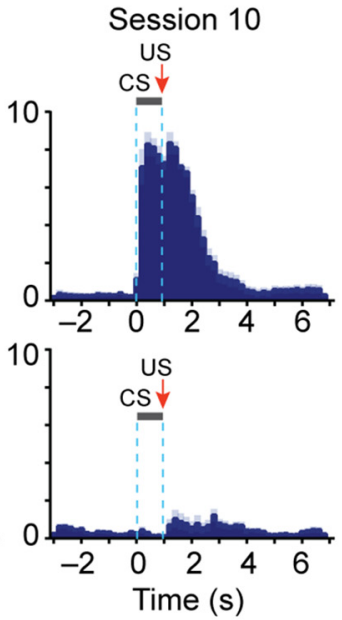

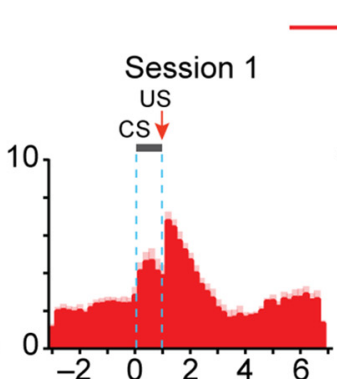

TeLC

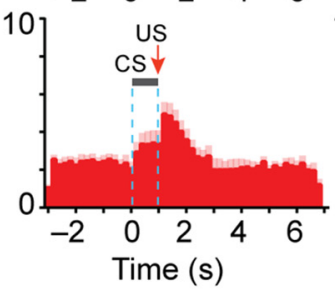

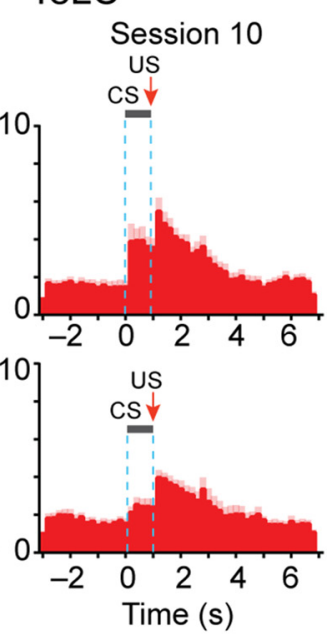

No-go trials

Overall
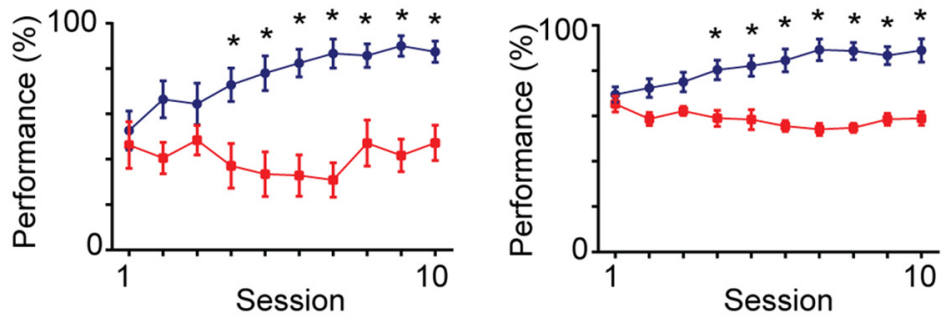

No-go trials

E

ITI licking
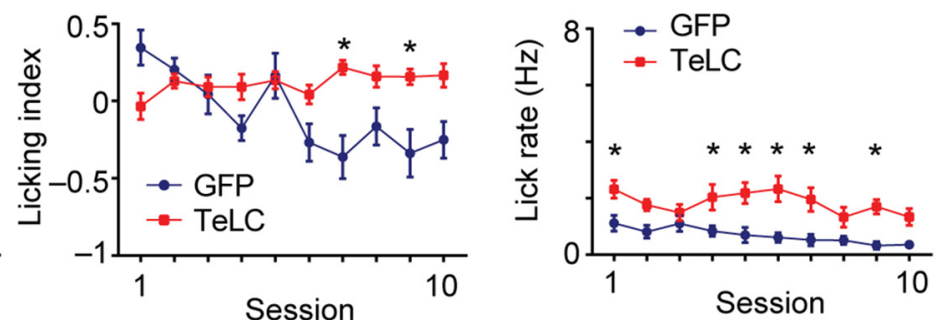

Following quinine delivery

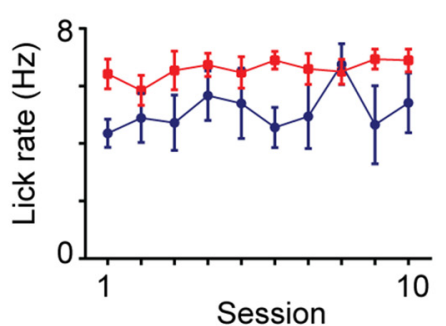

$\mathbf{F}$

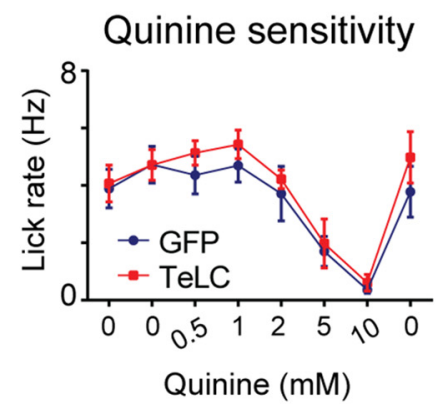

Figure 4. The IC-CeL circuit is required for suppression of behavioral responding. A, Population histogram of licking behavior during the first and final sessions of go/no-go training. Licking behavior is represented separately according to go (top) or no-go (bottom) trials for both GFP (blue; $n=9$ ) and TeLC (red; $n=7$ ) mice. Dashed line denotes the time window of CS delivery. US was delivered $50 \mathrm{~ms}$ after CS offset. Shaded regions represent SEM. B, Quantification of performance (the percentage of correct responding trials) on the go/no-go task. For the go trials, the TeLC animals showed a mild reduction in performance compared with GFP animals $\left({ }^{*} p<0.01\right)$. For the no-go trials, the TeLC animals showed a marked reduction in performance compared with GFP animals $\left({ }^{*} p<0.05\right)$. For the overall performance, the TeLC animals showed a reduction in performance compared with GFP animals $\left({ }^{*} p<0.01\right) . C$, TeLC animals showed decreased licking index in the go trials and increased licking index in the no-go trials ( $\left.{ }^{*} p<0.05\right)$. D, TeLC inhibition of the IC-CeL circuit did not affect the US-evoked licking rate $(p>0.05,2$-way RM ANOVA).E, TeLC inhibition of the IC-CeL circuit increased the intertrial licking rate $\left.{ }^{*} p<0.05\right)$. $F$, Quinine sensitivity test showing the lick rate during a 10 min free-licking session for various concentrations of quinine followed by a final session of water. TeLC inhibition of the IC-CeL circuit did not affect quinine sensitivity. All data are presented as mean \pm SEM. 
A

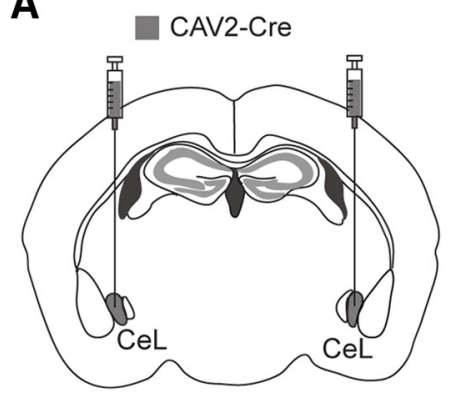

C

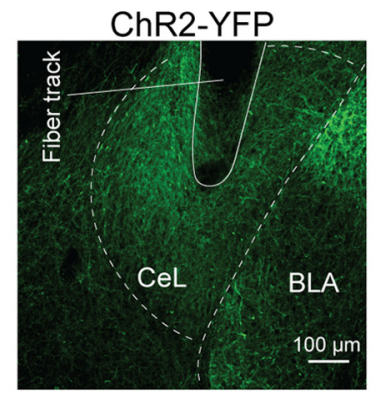

D

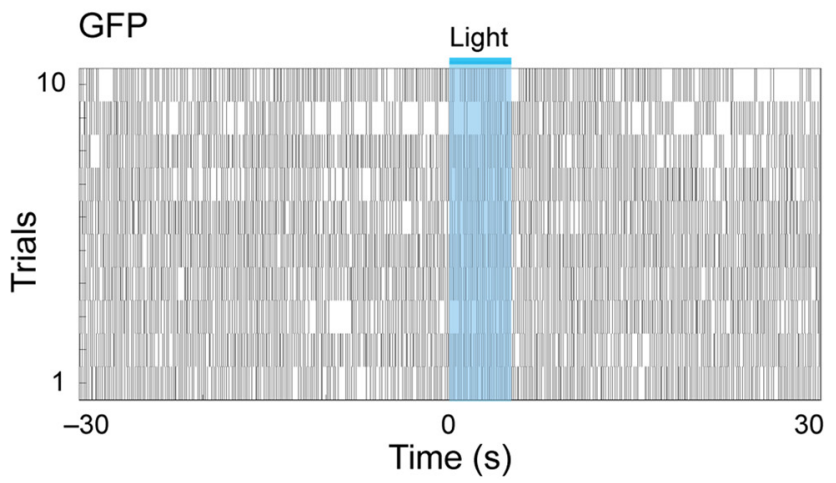

AAV-DIO-ChR2-YFP, or AAV-DIO-GFP

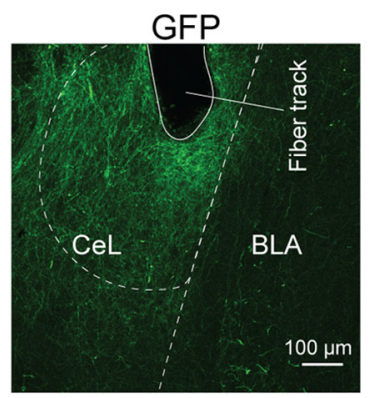

E
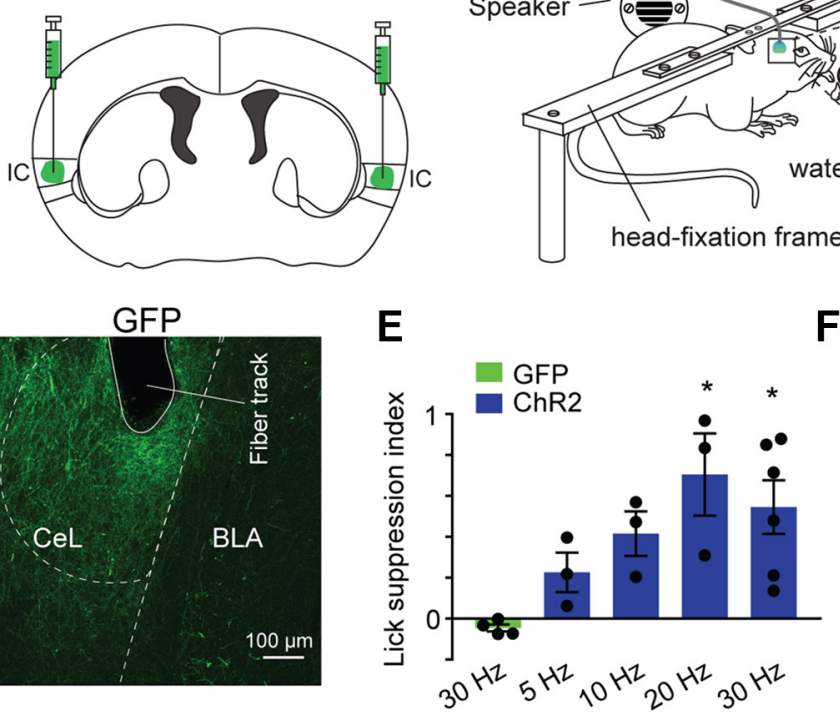

$F$

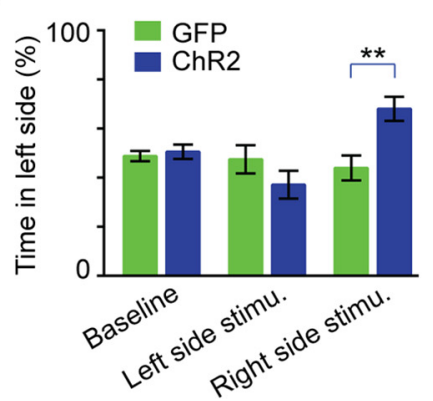

ChR2

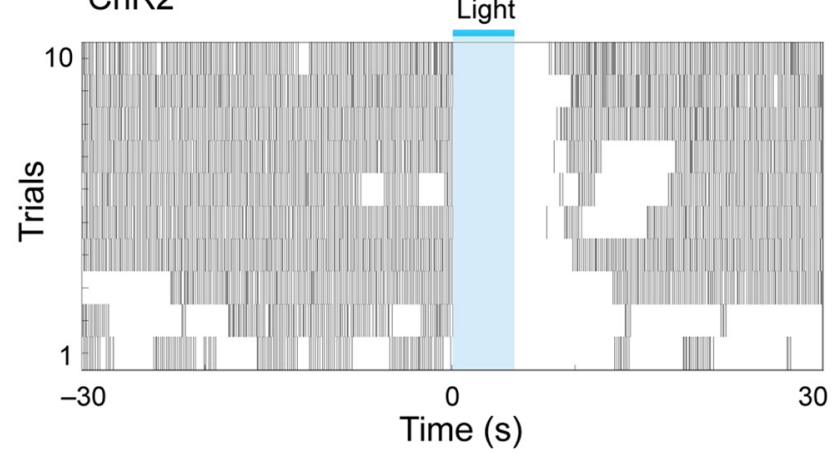

Figure 5. Optogenetic activation of the IC-CeL circuit is sufficient to induce action suppression and avoidance behavior. $\boldsymbol{A}, \boldsymbol{B}$, Schematics of the experimental design. $\boldsymbol{C}$, Representative images showing the locations of optical fiber implantation and green axon fibers in the CeL, which originated from CeL-projecting IC neurons expressing ChR2-YFP (left) or GFP (right). $\boldsymbol{D}$, Raster plots showing licking behavior for a GFP (left) and a ChR2 (right) animal. Blue bars and shaded areas indicate the time window of laser stimulation. $\boldsymbol{E}$, Quantification of the effect of the photostimulation on licking behavior (suppression index) at different stimulation frequencies ( ${ }^{*} p<0.05 ; 5-20 \mathrm{~Hz}, n=3 \mathrm{mice} ; 30 \mathrm{~Hz}, n=6$ mice). $\boldsymbol{F}$, In an RTPA behavioral paradigm, the ChR2 animals avoided the stimulation side ( ${ }^{* *} p=0.005 ; \mathrm{GFP}, n=4$ mice; (hR2, $n=6$ mice).

GFP mice showed similar cue-evoked responding in the laser-on or laser-off trials, whereas the ChR2 mice had lower cue-evoked responding in the laser-on trials than in the laser-off trials (Fig. $6 C)$. We also verified that the photostimulation did not cause obvious motor effects in either the ChR2 mice or the GFP mice in an open-field setting (Fig. 6E).

Of note, although optogenetic activation of the IC-CeL pathway was less effective than quinine reinforcement, we observed a pattern of responding in these mice qualitatively similar to that of the control animals trained on the standard sucrose/quinine go/ no-go task (Fig. 4B), in which the mice showed low levels of responding to the no-go cue and high levels of responding to the go cue. This pattern of responding was recapitulated in the cueevoked licking such that the ChR2 mice licked less (as measured by the licking index) than the GFP mice in response to CS in the laser-on trials but not laser-off trials (Fig. $6 D$; laser on: two-way ANOVA main effect of treatment, $F_{(1,54)}=26.32, p<0.0001$; main effect of session, $F_{(7,54)}=2.034, p=0.0673$; interaction, $F_{(7,54)}=0.2755, p=0.9609$; laser off: two-way ANOVA, $p>$ $0.05)$. Together, these results indicate that activation of the IC$\mathrm{CeL}$ pathway is sufficient to instruct the learning of anticipatory action suppression. This mechanism is likely engaged when learning to avoid an aversive outcome, such as an unpleasant tastant.

\section{Discussion}

In this study we examined the role of the IC-CeL circuit in the establishment of behavioral responding to cues predicting appetitive or aversive tastants. Using retrograde anatomic tracing approaches, including the modified rabies virus-assisted tracing, together with ChR2-based circuit mapping, we found that the GC region of the IC sends direct excitatory projections to the CeL, which make monosynaptic connections with both the $\mathrm{SOM}^{+}$ and $\mathrm{SOM}^{-} \mathrm{CeL}$ neurons, with the latter being mainly $\mathrm{PKC}-\delta^{+}$ neurons (Li et al., 2013; Penzo et al., 2014). Specific inhibition of the CeL-projecting IC neurons with TeLC prevented mice from acquiring the no-go response, and impaired the go response in a tastant (sucrose/quinine)-reinforced go/no-go task. Furthermore, selective activation of the IC-CeL pathway with optogenetics drove unconditioned lick suppression in thirsty animals, induced avoidance behavior, and was sufficient to instruct conditioned action suppression in response to the cue that predicts 


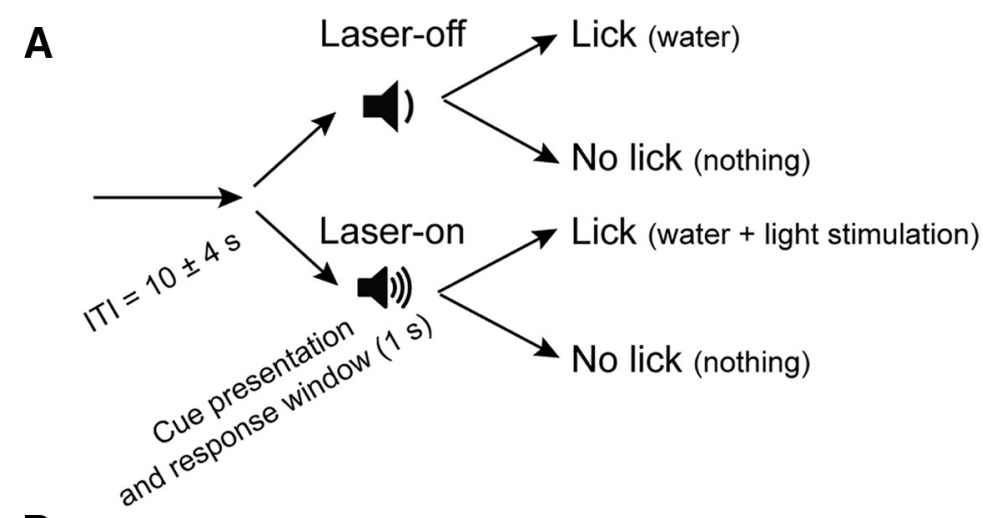

B

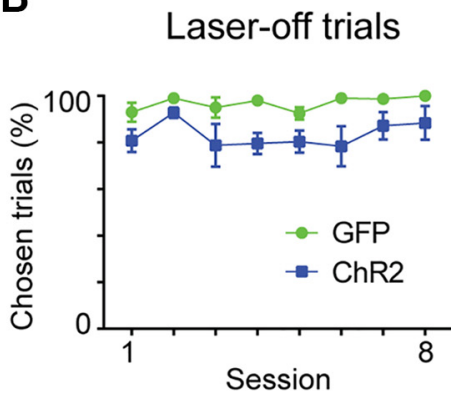

D

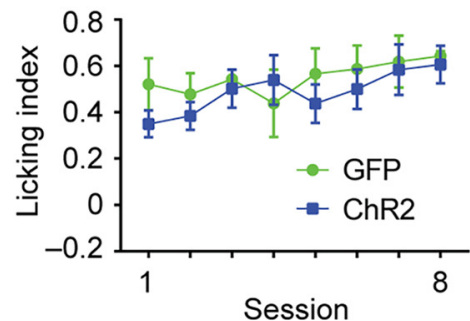

\section{Laser-on trials}

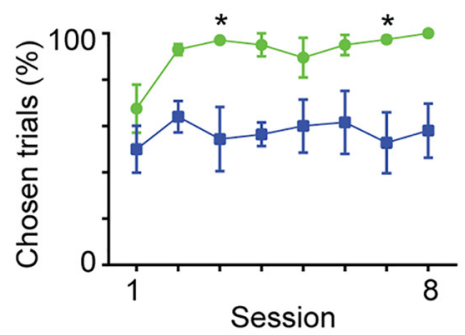

Laser-on trials



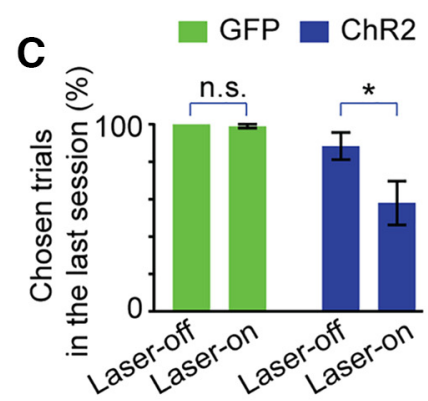
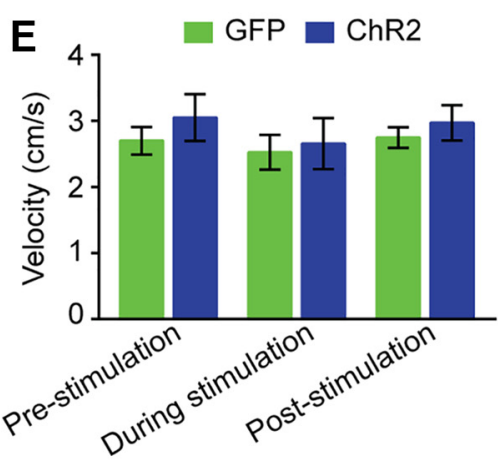

Figure 6. Optogenetic activation of the IC-CeL circuit is sufficient to instruct avoidance learning. $\boldsymbol{A}, A$ schematic of the experimental design. $\boldsymbol{B}$, Animal behavior is quantified as the percentage of trials that animals chose to lick during CS presentation (chosen trials; GFP, $n=4$ mice; ChR2, $n=5$ mice; ${ }^{*} p<0.05$ ). C, Quantification of the percentage of chosen trials in the final training session. $\boldsymbol{D}$, Animal behavior is quantified as the licking index (see Materials and Methods; GFP, $n=4$ mice, ChR2, $n=5$ mice; ${ }^{*} p<0.05$ ). $\boldsymbol{E}$, In an open field, laser stimulation did not affect movement of mice (GFP or ChR2 mice), measured as average movement velocity over 10 trials (GFP, $n=4$ mice; ChR2, $n=6$ mice; $p>0.05$ ). All data are presented as mean \pm SEM.

the optogenetic activation. Interestingly, although the IC has been shown to be required for identifying and discriminating between tastants (Katz et al., 2001; Peng et al., 2015; Sammons et al., 2016), we did not observe an effect on quinine sensitivity when we selectively silenced the IC-CeL pathway with TeLC (Fig. $4 F$ ), suggesting that the ability to process the basic reinforcing properties of bitter tastants are preserved in these mice, at least when cognitive demand is low. These results demonstrate that activity in the IC-CeL circuit is necessary for establishing anticipatory responses to either an unpleasant or appetitive tastant, and is also sufficient to drive learning of anticipatory avoidance responses.

The IC has been shown to contain regions with selective responses to distinct tastants (Chen et al., 2011). As measured in anesthetized animals, these "hotspots" occupy nonoverlapping regions within the GC. The region with preferential responses to bitter tastes resides in the posterior part of the GC, which corresponds approximately to the area of IC we identified that sends the strongest projections to the CeL (Allen et al., 1991). These findings suggest that the IC may convey information about bitter/ aversive tastants to the CeL, which in turn drives behavioral inhibition.

The CeA, including the CeL, receives aversive information of different modalities directly from the brainstem parabrachial nucleus (Norgren et al., 1989; Carter et al., 2013; Han et al., 2015; Sato et al., 2015). Previous studies have shown that the CeA responds to noxious stimuli, such as footshocks that induce somatic pain (Radulovic et al., 1998; Han et al., 2015), colorectal distension that induces visceral pain (Myers and GreenwoodVan Meerveld, 2012), and lithium chloride, which induces malaise and is the most commonly used US for inducing CTA (Lamprecht and Dudai, 1995). The CeA has also been implicated in taste processing (Sadacca et al., 2012) and feeding behaviors (Cai et al., 2014). Thus, the CeA is anatomically poised to process convergent somatosensory, visceral, gustatory, and aversive information and may be recruited by multiple neural circuits for action suppression in a variety of tasks, in which the goal is to avoid unwanted consequences.

More recent studies, including our own, indicate that the CeA contains functionally heterogeneous neuronal populations. 
$\mathrm{SOM}^{+} \mathrm{CeL}$ neurons control passive defensive responses, such as freezing and action suppression (Li et al., 2013; Penzo et al., 2014, 2015; Yu et al., 2016; Fadok et al., 2017). SOM ${ }^{+}$neurons and other genetically identified cell types in the CeL also play an important role in generating appetitive behaviors (Douglass et al., 2017; Kim et al., 2017). Furthermore, PKC- $\delta^{+}$CeL neurons are involved in conveying aversive US information and instructing aversive learning (Yu et al., 2017). The PKC- $\delta^{+}$CeL neurons have also been linked to suppression of feeding (Cai et al., 2014). As both $\mathrm{SOM}^{+}$cells and $\mathrm{SOM}^{-}$cells in the CeL receive direct excitatory inputs from the IC (Fig. 1), they may contribute to distinct aspects of the IC-CeL circuit function described in the current study. An intriguing possibility is that, when engaged by IC inputs, the $\mathrm{SOM}^{+}$population contributes to responses in both the go and the no-go trials, while the PKC- $\delta^{+}$population regulates learning and potentially aversion in go/no-go tasks. Some of the functions mediated by CeL neurons, in particular those by PKC- $\delta^{+}$neurons, are consistent with the findings that the CeA plays a role in alerting or attentional processes (Yu et al., 2017), and can explain our observations suggesting that the ICCeL circuit may have a more general function in behavior, i.e., it influences learning and performance during not only the no-go trials, but also the go trials of the go/no-go task.

\section{References}

Accolla R, Carleton A (2008) Internal body state influences topographical plasticity of sensory representations in the rat gustatory cortex. Proc Natl Acad Sci U S A 105:4010-4015. CrossRef Medline

Ahrens S, Jaramillo S, Yu K, Ghosh S, Hwang GR, Paik R, Lai C, He M, Huang ZJ, Li B (2015) ErbB4 regulation of a thalamic reticular nucleus circuit for sensory selection. Nat Neurosci 18:104-111. CrossRef Medline

Allen GV, Saper CB, Hurley KM, Cechetto DF (1991) Organization of visceral and limbic connections in the insular cortex of the rat. J Comp Neurol 311:1-16. CrossRef Medline

Bermúdez-RattoniF (2004) Molecular mechanisms of taste-recognition memory. Nat Rev Neurosci 5:209-217. CrossRef Medline

Bru T, Salinas S, Kremer EJ (2010) An update on canine adenovirus type 2 and its vectors. Viruses 2:2134-2153. CrossRef Medline

Cai H, Haubensak W, Anthony TE, Anderson DJ (2014) Central amygdala PKC-delta $(+)$ neurons mediate the influence of multiple anorexigenic signals. Nat Neurosci 17:1240-1248. CrossRef Medline

Callaway EM, Luo L (2015) Monosynaptic circuit tracing with glycoprotein-deleted rabies viruses. J Neurosci 35:8979-8985. CrossRef Medline

Carter ME, Soden ME, Zweifel LS, Palmiter RD (2013) Genetic identification of a neural circuit that suppresses appetite. Nature 503:111-114. CrossRef Medline

Chen X, Gabitto M, Peng Y, Ryba NJ, Zuker CS (2011) A gustotopic map of taste qualities in the mammalian brain. Science 333:1262-1266. CrossRef Medline

Ciocchi S, Herry C, Grenier F, Wolff SB, Letzkus JJ, Vlachos I, Ehrlich I, Sprengel R, Deisseroth K, Stadler MB, Müller C, Lüthi A (2010) Encoding of conditioned fear in central amygdala inhibitory circuits. Nature 468:277-282. CrossRef Medline

Douglass AM, Kucukdereli H, Ponserre M, Markovic M, Gründemann J, Strobel C, Alcala Morales PL, Conzelmann KK, Lüthi A, Klein R (2017) Central amygdala circuits modulate food consumption through a positive-valence mechanism. Nat Neurosci 20:1384-1394. CrossRef Medline

Fadok JP, Krabbe S, Markovic M, Courtin J, Xu C, Massi L, Botta P, Bylund K, Müller C, Kovacevic A, Tovote P, Lüthi A (2017) A competitive inhibitory circuit for selection of active and passive fear responses. Nature 542: 96-100. CrossRef Medline

Gallagher M, Graham PW, Holland PC (1990) The amygdala central nucleus and appetitive Pavlovian conditioning: lesions impair one class of conditioned behavior. J Neurosci 10:1906-1911. Medline

Gardner MP, Fontanini A (2014) Encoding and tracking of outcomespecific expectancy in the gustatory cortex of alert rats. J Neurosci 34: 13000-13017. CrossRef Medline

Goosens KA, Maren S (2003) Pretraining NMDA receptor blockade in the basolateral complex, but not the central nucleus, of the amygdala prevents savings of conditional fear. Behav Neurosci 117:738-750. CrossRef Medline

Guzman-Ramos K, Bermudez-Rattoni F (2012) Interplay of amygdala and insular cortex during and after associative taste aversion memory formation. Rev Neurosci 23:463-471. CrossRef Medline

Han S, Soleiman MT, Soden ME, Zweifel LS, Palmiter RD (2015) Elucidating an affective pain circuit that creates a threat memory. Cell 162:363374. CrossRef Medline

Hashimoto K, Spector AC (2014) Extensive lesions in the gustatory cortex in the rat do not disrupt the retention of a presurgically conditioned taste aversion and do not impair unconditioned concentration-dependent licking of sucrose and quinine. Chem Senses 39:57-71. CrossRef Medline

Haubensak W, Kunwar PS, Cai H, Ciocchi S, Wall NR, Ponnusamy R, Biag J, Dong HW, Deisseroth K, Callaway EM, Fanselow MS, Lüthi A, Anderson DJ (2010) Genetic dissection of an amygdala microcircuit that gates conditioned fear. Nature 468:270-276. CrossRef Medline

Katz DB, Simon SA, Nicolelis MA (2001) Dynamic and multimodal responses of gustatory cortical neurons in awake rats. J Neurosci 21:44784489. Medline

Kentridge RW, Shaw C, Aggleton JP (1991) Amygdaloid lesions and stimulus-reward associations in the rat. Behav Brain Res 42:57-66. CrossRef Medline

Kim J, Zhang X, Muralidhar S, LeBlanc SA, Tonegawa S (2017) Basolateral to central amygdala neural circuits for appetitive behaviors. Neuron 93 : 1464-1479.e5. CrossRef Medline

Kusumoto-Yoshida I, Liu H, Chen BT, Fontanini A, Bonci A (2015) Central role for the insular cortex in mediating conditioned responses to anticipatory cues. Proc Natl Acad Sci U S A 112:1190-1195. CrossRef Medline

Lamprecht R, Dudai Y (1995) Differential modulation of brain immediate early genes by intraperitoneal LiCl. Neuroreport 7:289-293. Medline

Li H, Penzo MA, Taniguchi H, Kopec CD, Huang ZJ, Li B (2013) Experience-dependent modification of a central amygdala fear circuit. Nat Neurosci 16:332-339. CrossRef Medline

Li L, Tasic B, Micheva KD, Ivanov VM, Spletter ML, Smith SJ, Luo L (2010) Visualizing the distribution of synapses from individual neurons in the mouse brain. PLoS One 5:e11503. CrossRef Medline

Livneh Y, Ramesh RN, Burgess CR, Levandowski KM, Madara JC, Fenselau H, Goldey GJ, Diaz VE, Jikomes N, Resch JM, Lowell BB, Andermann ML (2017) Homeostatic circuits selectively gate food cue responses in insular cortex. Nature 546:611-616. CrossRef Medline

Madisen L, Zwingman TA, Sunkin SM, Oh SW, Zariwala HA, Gu H, Ng LL, Palmiter RD, Hawrylycz MJ, Jones AR, Lein ES, Zeng H (2010) A robust and high-throughput Cre reporting and characterization system for the whole mouse brain. Nat Neurosci 13:133-140. CrossRef Medline

Maffei A, Haley M, Fontanini A (2012) Neural processing of gustatory information in insular circuits. Curr Opin Neurobiol 22:709-716. CrossRef Medline

McDonald AJ (1998) Cortical pathways to the mammalian amygdala. Prog Neurobiol 55:257-332. CrossRef Medline

Murray AJ, Sauer JF, Riedel G, McClure C, Ansel L, Cheyne L, Bartos M, Wisden W, Wulff P (2011) Parvalbumin-positive CA1 interneurons are required for spatial working but not for reference memory. Nat Neurosci 14:297-299. CrossRef Medline

Myers B, Greenwood-Van Meerveld B (2012) Differential involvement of amygdala corticosteroid receptors in visceral hyperalgesia following acute or repeated stress. Am J Physiol Gastrointest Liver Physiol 302:G260 G266. CrossRef Medline

Norgren R, Nishijo H, Travers SP (1989) Taste responses from the entire gustatory apparatus. Ann N Y Acad Sci 575:246-263; discussion 263-264. Medline

Peng Y, Gillis-Smith S, Jin H, Tränkner D, Ryba NJ, Zuker CS (2015) Sweet and bitter taste in the brain of awake behaving animals. Nature 527:512515. CrossRef Medline

Penzo MA, Robert V, Li B (2014) Fear conditioning potentiates synaptic transmission onto long-range projection neurons in the lateral subdivision of central amygdala. J Neurosci 34:2432-2437. CrossRef Medline

Penzo MA, Robert V, Tucciarone J, De Bundel D, Wang M, Van Aelst L, Darvas M, Parada LF, Palmiter RD, He M, Huang ZJ, Li B (2015) The paraventricular thalamus controls a central amygdala fear circuit. Nature 519:455-459. CrossRef Medline

Petrovich GD, Ross CA, Mody P, Holland PC, Gallagher M (2009) Central, 
but not basolateral, amygdala is critical for control of feeding by aversive learned cues. J Neurosci 29:15205-15212. CrossRef Medline

Radulovic J, Kammermeier J, Spiess J (1998) Relationship between fos production and classical fear conditioning: effects of novelty, latent inhibition, and unconditioned stimulus preexposure. J Neurosci 18:7452-7461. Medline

Robinson MJ, Warlow SM, Berridge KC (2014) Optogenetic excitation of central amygdala amplifies and narrows incentive motivation to pursue one reward above another. J Neurosci 34:16567-16580. CrossRef Medline

Sadacca BF, Rothwax JT, Katz DB (2012) Sodium concentration coding gives way to evaluative coding in cortex and amygdala. J Neurosci 32: 9999-10011. CrossRef Medline

Sammons J, Bass C, Victor J, Di Lorenzo P (2016) Gustatory cortical input onto the nucleus of the solitary tract refines neuronal firing patterns and enhances learning in the awake rat. Paper Presented at Society for Neuroscience 2016 Annual Meeting, San Diego, November.

Samuelsen CL, Fontanini A (2017) Processing of intraoral olfactory and gustatory signals in the gustatory cortex of awake rats. J Neurosci 37:244257. CrossRef Medline

Sato M, Ito M, Nagase M, Sugimura YK, Takahashi Y, Watabe AM, Kato F (2015) The lateral parabrachial nucleus is actively involved in the acquisition of fear memory in mice. Mol Brain 8:22. CrossRef Medline

Seo DO, Funderburk SC, Bhatti DL, Motard LE, Newbold D, Girven KS, McCall JG, Krashes M, Sparta DR, Bruchas MR (2016) A GABAergic projection from the centromedial nuclei of the amygdala to ventromedial prefrontal cortex modulates reward behavior. J Neurosci 36:1083110842. CrossRef Medline

Stephenson-Jones M, Yu K, Ahrens S, Tucciarone JM, van Huijstee AN, Mejia
LA, Penzo MA, Tai LH, Wilbrecht L, Li B (2016) A basal ganglia circuit for evaluating action outcomes. Nature 539:289-293. CrossRef Medline

Taniguchi H, He M, Wu P, Kim S, Paik R, Sugino K, Kvitsiani D, Kvitsani D, Fu Y, Lu J, Lin Y, Miyoshi G, Shima Y, Fishell G, Nelson SB, Huang ZJ (2011) A resource of Cre driver lines for genetic targeting of GABAergic neurons in cerebral cortex. Neuron 71:995-1013. CrossRef Medline

Vincis R, Fontanini A (2016) Associative learning changes cross-modal representations in the gustatory cortex. Elife 5:pii:e16420 CrossRef Medline

Wilensky AE, Schafe GE, Kristensen MP, LeDoux JE (2006) Rethinking the fear circuit: the central nucleus of the amygdala is required for the acquisition, consolidation, and expression of Pavlovian fear conditioning. J Neurosci 26:12387-12396. CrossRef Medline

Yamamoto T, Yuyama N, Kato T, Kawamura Y (1985) Gustatory responses of cortical neurons in rats. II. Information processing of taste quality. J Neurophysiol 53:1356-1369. CrossRef Medline

Yasoshima Y, Yamamoto T (1998) Short-term and long-term excitability changes of the insular cortical neurons after the acquisition of taste aversion learning in behaving rats. Neuroscience 84:1-5. CrossRef Medline

Yu K, Garcia da Silva P, Albeanu DF, Li B (2016) Central amygdala somatostatin neurons gate passive and active defensive behaviors. J Neurosci 36:6488-6496. CrossRef Medline

Yu K, Ahrens S, Zhang X, Schiff H, Ramakrishnan C, Fenno L, Deisseroth K, Zhao F, Luo MH, Gong L, He M, Zhou P, Paninski L, Li B (2017) The central amygdala controls learning in the lateral amygdala. Nat Neurosci 20:1680-1685. CrossRef Medline

Zhang F, Wang LP, Boyden ES, Deisseroth K (2006) Channelrhodopsin-2 and optical control of excitable cells. Nat Methods 3:785-792. CrossRef Medline 